\title{
Hepatitis B Awareness and Knowledge in Asian Communities in British Columbia
}

\author{
Alan Hoi Lun Yau, ${ }^{1}$ Jo-Ann Ford, ${ }^{1}$ Peter Wing Cheung Kwan, ${ }^{1}$ Jessica Chan, ${ }^{2}$ \\ Queenie Choo, ${ }^{2}$ Tim K. Lee, ${ }^{3,4}$ Willie Kwong, ${ }^{2}$ Alan Huang, ${ }^{2}$ and Eric Yoshida ${ }^{1}$ \\ ${ }^{1}$ Division of Gastroenterology, Department of Medicine, University of British Columbia, GLDHCC, 2775 Laurel Street, \\ 5th Floor, Vancouver, BC, Canada V5Z $1 M 9$ \\ ${ }^{2}$ S.U.C.C.E.S.S., 555 Carrall Street, Vancouver, BC, Canada V6B $2 J 8$ \\ ${ }^{3}$ Cancer Control Research Program, BC Cancer Agency, 675 West 10th Avenue, Vancouver, BC, Canada V5Z 1L3 \\ ${ }^{4}$ School of Population and Public Health, University of British Columbia, 2206 East Mall, Vancouver, BC, Canada V6T $1 Z 9$
}

Correspondence should be addressed to Eric Yoshida; eric.yoshida@vch.ca

Received 3 September 2015; Accepted 9 November 2015

\begin{abstract}
Copyright (C) 2016 Alan Hoi Lun Yau et al. This is an open access article distributed under the Creative Commons Attribution License, which permits unrestricted use, distribution, and reproduction in any medium, provided the original work is properly cited.

Background. Our study examined hepatitis B virus (HBV) awareness and knowledge in Asian communities in British Columbia (BC). Methods. A statistical random sample representation of Chinese, Korean, Filipino, South Asian, and Southeast Asian populations in Greater Vancouver was surveyed by telephone. Multiple logistic regression analysis was performed to identify predictors of HBV knowledge. Results. General awareness of HBV was reported in 78.8\% (798/1013). HBV awareness was the highest in Chinese (89\%) and Filipino (88\%) populations and the lowest in the South Asian (56\%) population. "Reasonable" knowledge of HBV was elicited in $76.8 \%$ (778/1013). Higher HBV knowledge was associated with younger age $(p=0.014)$, higher education $(p<0.0001)$, Chinese ethnicity $(p<0.0001)$, and use of media $(p=0.01)$ and Internet $(p=0.024)$ for health information. Compared to the Chinese $(\mathrm{OR}=1.0)$ population, "reasonable" knowledge of HBV was lower in Korean $(\mathrm{OR}=0.3,95 \% \mathrm{CI}$ : 0.1-0.5), Filipino (OR $=0.3,95 \%$ CI: 0.2-0.6), South Asian (OR = 0.3, 95\% CI: 0.2-0.4), and Southeast Asian (OR = 0.3, 95\% CI: 0.1$0.6)$ populations. $54.8 \%(555 / 1013)$ felt that HBV education was inadequate and $80.1 \%(811 / 1013)$ preferred HBV education in their native languages. Conclusion. Compared to the Chinese population, other Asian communities in BC have lower HBV awareness and knowledge. Public education should target older and less educated and Korean, Filipino, South Asian, and Southeast Asian populations in their native languages via media and Internet.
\end{abstract}

\section{Introduction}

In Asia, hepatitis B virus (HBV) infection is highly endemic where $70-90 \%$ of the population become infected by the age of 40 and where $8-20 \%$ are chronic carriers [1]. Canada is a country with low endemicity for HBV where $0.8 \%$ of the population (180,000 individuals) are chronic carriers [2]. However, among the Canadian provinces, British Columbia (BC) has the highest proportion of Asians in its population, which includes Chinese (10.6\%), South Asian (6.5\%), East and Southeast Asian (16.0\%), and East Indian (5.7\%) populations [3]. In $\mathrm{BC}, 6 \%$ of the Chinese immigrants are chronic carriers of HBV [4]. Chronic HBV infection results in cirrhosis in 20-40\% [5], increases the risk of hepatocellular carcinoma 100-fold [5], and leads to 500,000-700,000 deaths annually worldwide [6].
Given the significant morbidity and mortality associated with chronic HBV infection, the previously reported rates of HBV vaccination (29-38\%) and screening (39-57\%) among Chinese immigrants in $\mathrm{BC}$ are suboptimal and concerning [4, 7]. An association between increased rates of vaccination and screening for HBV and a greater knowledge of HBV has been consistently demonstrated in multiple studies [7-16]. Hence, continuing efforts in community education may promote uptake of preventive measures and therapeutic interventions for HBV, thereby alleviating the increasing burden of HBV on the Canadian health care system. However, in a survey conducted in BC in 2005 , only $13 \%$ of the Chinese immigrants felt that HBV education was adequate in the community [17]. In order to improve the effectiveness of community health education campaigns, it is essential to gain a thorough understanding of the public awareness and knowledge of HBV. 
We performed a telephone survey on a statistical random sample representation of the Asian populations residing within the Greater Vancouver Regional District (GVRD). Our aims were to (1) evaluate public awareness and knowledge of HBV; (2) identify sociodemographic variables associated with HBV knowledge; and (3) gather public opinion on the preferred source and language of HBV education in the community.

\section{Methods}

2.1. Population Sampling. From April 16, 2012, to May 4, 2012, 1013 individuals participated in a telephone interview conducted in one of seven different languages by an external company called Select Field Services. Prospective respondents were called at least three times at different times of the day before a prospective respondent was dropped and replaced with another. A sampling frame based on pertinent surnames of all targeted ethnic households residing within GVRD was purchased to obtain a list of telephone numbers which were imported into a Computer-Assisted Telephone Interviewing (CATI) system. A total sample size of 1000 to 1200 successful interviews was predetermined in order to achieve the statistical representation and to produce survey results with a 95\% confidence interval for the outcome of $\mathrm{HBV}$ awareness and knowledge. Sampling quotas are preset in proportion to the overall size of each ethnic group via proportional random sampling. Random selection of households and of a particular adult within each selected household was performed by CATI. The ethnic groups sampled were Chinese (Mainland China, Hong Kong, and Taiwan); Korean; Filipino; South Asian (East Indian, Bangladeshi, Bengali, Goan, Gujarati, Kashmiri, Nepali, Pakistani, Punjabi, Sinhalese, Sri Lankan, and Tamil); and Southeast Asian (Vietnamese, Laotian, Cambodian, Singaporean, Malaysian, Indonesian, and Burmese) populations. The study was approved by the University of British Columbia Behavioural Research Ethics Board.

2.2. Survey Instrument. A standardized questionnaire was developed in English, translated into five different languages, administered in the respondents' native language, and backtranslated to English to ensure accuracy. The questionnaire contained five sections including questions on sociodemographics, health care utilization, HBV awareness, HBV knowledge, and HBV education (see Supplementary Material available online at http://dx.doi.org/10.1155/2016/4278724).

2.3. Statistical Analysis. HBV knowledge was considered "reasonable" if respondents correctly answered 7 or more of the 13 questions. Associations between demographic and knowledge variables were assessed using $\chi^{2}$ test. Independent predictors of $\mathrm{HBV}$ knowledge were identified by multiple logistic regression forward stepwise analysis. Tests for trend across category groupings of age and education were conducted by treating the participant age and education level as continuous variables. Statistical significance was achieved if two-tailed $p<0.05$. Data were analyzed using SPSS version
20.0 (IBM Corporation, USA) for Windows XP (Microsoft Corporation, USA).

\section{Results}

3.1. Sample Characteristics (Table 1). A total of 1013 individuals participated in the survey. The majority $(66 \%)$ of respondents were below 55 years of age. There were similar numbers of male and female respondents (44\% and 56\%, resp.). The ethnicities of the respondents were Chinese (51.2\%), Korean (6.2\%), Filipino (11.6\%), South Asian (27.0\%), and Southeast Asian (3.8\%). The majority of respondents were relatively well educated with postsecondary education in $20 \%$ and university education in $45 \%$. The majority were bilingual (88\%) and had family physicians (93\%).

3.2. HBV Testing, Diagnosis, and Treatment. HBV testing was performed in $48.3 \%(489 / 1013)$, and HBV was diagnosed in $5.6 \%(57 / 1013)$, of which $70.2 \%(40 / 57)$ were not receiving treatment for $\mathrm{HBV}$, and $87.7 \%(50 / 57)$ were not taking medication for HBV. A family history of $\mathrm{HBV}$ infection was present in $8 \%$.

3.3. HBV Awareness (Table 2). General awareness of HBV was reported in $78.8 \%(798 / 1013)$. HBV awareness was the highest in the Chinese $(89 \%)$ and Filipino (88\%) populations and the lowest in the South Asian (56\%) population. 48.9\% (495/1013) felt that HBV was a concern for the community.

3.4. HBV Knowledge (Table 3). 76.8\% (778/1013) demonstrated a "reasonable" level of HBV knowledge. A low proportion of individuals were aware that HBV could lead to chronic disease $(61 \%)$, cirrhosis $(62 \%)$, and hepatocellular carcinoma (62\%). Perinatal and sexual transmission of HBV were recognized by $68 \%$ and $37 \%$ of respondents, respectively; however, only $26 \%$ of respondents knew that HBV cannot be transmitted by sharing food or utensils with an infected person. The majority of respondents knew that HBV can be diagnosed by blood tests (84\%) and that HBV can be prevented by vaccine $(71 \%)$, but only $53 \%$ were aware of the effective treatment for HBV.

3.5. Multivariate Analysis (Tables 4 and 5). Higher $\mathrm{HBV}$ knowledge was statistically significantly associated with younger age $(p=0.014)$, higher education $(p<0.0001)$, Chinese ethnicity $(p<0.0001)$, and use of media $(p=0.001)$ and Internet $(p=0.024)$ for health information. Knowledge that HBV may cause cirrhosis was statistically significantly associated with higher education $(p<0.0001)$, Chinese ethnicity $(p<0.0001)$, and use of media for health information $(p=$ $0.009)$. Knowledge that HBV may cause liver cancer was statistically significantly associated with Chinese ethnicity $(p<$ 0.0001) (data not shown). Compared to the Chinese $(\mathrm{OR}=$ 1.0) population, "reasonable" knowledge of $\mathrm{HBV}$ was lower in Korean ( $\mathrm{OR}=0.3,95 \% \mathrm{CI}$ : 0.1-0.5), Filipino $(\mathrm{OR}=0.3$, 95\% CI: 0.2-0.6), South Asian (OR = 0.3, 95\% CI: 0.2-0.4), and Southeast Asian (OR = 0.3, 95\% CI: 0.1-0.6) populations. 
TABLE 1: Baseline characteristics of survey respondents.

\begin{tabular}{|c|c|}
\hline Characteristics & $N(\%)$ \\
\hline \multicolumn{2}{|l|}{ Age } \\
\hline $19-24$ & $78(7.7)$ \\
\hline $25-39$ & $252(24.9)$ \\
\hline $40-54$ & $336(33.2)$ \\
\hline$\geq 55$ & $343(33.9)$ \\
\hline \multicolumn{2}{|l|}{ Gender } \\
\hline Male & $448(44.2)$ \\
\hline Female & $565(55.8)$ \\
\hline \multicolumn{2}{|l|}{ Ethnicity } \\
\hline Chinese & $519(51.2 \%)$ \\
\hline South Asian & $274(27.0)$ \\
\hline Filipino & $118(11.6)$ \\
\hline Korean & $63(6.2)$ \\
\hline Southeast Asian & $39(3.8)$ \\
\hline \multicolumn{2}{|l|}{ Status in Canada } \\
\hline Citizen & $751(74.1)$ \\
\hline Permanent resident & $239(23.6)$ \\
\hline $\begin{array}{l}\text { Nonresident (temporary foreign worker, student, or } \\
\text { visitor) }\end{array}$ & $23(2.3)$ \\
\hline \multicolumn{2}{|l|}{ Language spoken at home } \\
\hline Chinese (Cantonese and Mandarin) & $513(50.6)$ \\
\hline English & $83(8.2)$ \\
\hline Korean & $48(4.7)$ \\
\hline Southeast Asian languages & $104(10.3)$ \\
\hline South Asian languages & $256(25.3)$ \\
\hline Other languages & $9(0.9)$ \\
\hline \multicolumn{2}{|l|}{ Second language at home } \\
\hline English & $807(79.7)$ \\
\hline French & $3(0.3)$ \\
\hline Spanish & $4(0.4)$ \\
\hline None & $126(12.4)$ \\
\hline \multicolumn{2}{|l|}{ Education } \\
\hline Primary/elementary & $91(9.0)$ \\
\hline Secondary & $253(25.0)$ \\
\hline Postsecondary & $199(19.6)$ \\
\hline University & $453(44.7)$ \\
\hline \multicolumn{2}{|l|}{ Working } \\
\hline Yes & $484(47.8)$ \\
\hline No & $525(51.8)$ \\
\hline \multicolumn{2}{|l|}{ Having a family doctor } \\
\hline Yes & $944(93.2)$ \\
\hline No & $68(6.8)$ \\
\hline \multicolumn{2}{|l|}{ Physical checkup } \\
\hline Yes & $729(72.0)$ \\
\hline No & $284(28.0)$ \\
\hline
\end{tabular}

3.6. HBV Education (Table 6). 54.8\% (555/1013) felt that HBV education was inadequate in the community. $80.1 \%(811 / 1013)$ preferred HBV education in their native languages. The main sources of health information were doctor's office $(58 \%)$, Internet (41\%), and media (40\%). There was a significant association $(p<0.0001)$ between younger age and use of Internet for health information $(56.4 \%$ at the age of $19-$ $24,55.2 \%$ at the age of $25-39,39.9 \%$ at the age of $40-54$, and $28.0 \%$ at the age of $\geq 55$ ). Only $20 \%$ of respondents felt that $\mathrm{HBV}$ has received sufficient funding support from the $\mathrm{BC}$ government for preventive health education and patient care, compared to tuberculosis (23\%), chronic obstructive pulmonary disease (24\%), hypertension (34\%), HIV/AIDS (34\%), diabetes (41\%), and cancer $(42 \%)$.

\section{Discussion}

In the present study, $\mathrm{HBV}$ awareness was reported in $79 \%$ of the respondents, which is consistent with the rate of 68$85 \%$ in previous studies examining Chinese immigrants in BC $[7,17]$. However, awareness may not reflect knowledge, and many respondents in our study had misconceptions in the natural history, transmission modes, and health consequences of HBV. Furthermore, although $84 \%$ of respondents knew that HBV can be diagnosed by blood tests, only $48 \%$ have ever been tested for $\mathrm{HBV}$, despite having a family physician in 93\%. This latter finding suggests knowledge deficits of family physicians in the availability of effective treatment for HBV, further reinforcing the need for greater educational efforts in HBV among primary care physicians.

Chinese ethnicity was identified as a positive predictor of higher HBV knowledge in our study. Significantly more Chinese respondents knew that $\mathrm{HBV}$ may cause cirrhosis or liver cancer, and overall HBV knowledge was higher in the Chinese population compared to other Asian ethnic groups. Previous studies have also reported knowledge deficits in HBV in Korean [18, 19], South Asian [20-24], and Southeast Asian $[10,13,15,16,25-31]$ populations. The differences in HBV knowledge among Asian populations in BC may be attributed to the introduction of HBV educational campaigns to the local Chinese media via radio and newspaper in 2007. Indeed, the use of media for health information was identified as a positive predictor of higher $\mathrm{HBV}$ knowledge in our study. Hence, our findings indicate an urgent need to expand community education on HBV to other Asian ethnic groups.

Younger age was found to be a positive predictor of higher HBV knowledge in our study, in contrast to a previous study performed in 2005 which identified an association with older age among Chinese immigrants in BC [17]. A possible explanation is that the Internet is being utilized more frequently in recent years by younger individuals for health information and this was confirmed by the significant association between younger age and use of Internet for health information in our study. A study in Taiwan evaluating an education program via the Internet for university students found that it was welcomed by $68 \%$ and that it significantly improved their HBV knowledge [32]. Indeed, the use of Internet for health information was identified as a positive predictor of higher HBV knowledge in our study.

Higher education was another positive predictor of higher HBV knowledge in our study. Such an association 
TABLE 2: HBV awareness of survey respondents.

\begin{tabular}{|c|c|c|c|c|c|c|}
\hline $\begin{array}{l}\text { Hepatitis B awareness } \\
N(\%)\end{array}$ & $\begin{array}{c}\text { Total } \\
(N=1013)\end{array}$ & $\begin{array}{l}\text { Chinese } \\
(N=522)\end{array}$ & $\begin{array}{l}\text { South Asian } \\
(N=274)\end{array}$ & $\begin{array}{l}\text { Filipino } \\
(N=117)\end{array}$ & $\begin{array}{l}\text { Korean } \\
(N=60)\end{array}$ & $\begin{array}{l}\text { Southeast Asian } \\
\qquad(N=39)\end{array}$ \\
\hline \multicolumn{7}{|l|}{$\begin{array}{l}\text { Are you aware of a } \\
\text { disease called } \\
\text { hepatitis B? }\end{array}$} \\
\hline Yes & $798(78.8)$ & $465(89.0)$ & $152(55.5)$ & $103(88.1)$ & $46(76.2)$ & $32(82.1)$ \\
\hline No & $184(18.2)$ & $49(9.4)$ & $109(39.8)$ & $10(8.5)$ & $10(17.5)$ & $5(12.8)$ \\
\hline Uncertain & $31(3.1)$ & $8(1.5)$ & $13(4.7)$ & $4(3.4)$ & $4(6.3)$ & $2(5.1)$ \\
\hline \multicolumn{7}{|l|}{$\begin{array}{l}\text { Is hepatitis B a } \\
\text { concern of the Asian } \\
\text { community? }\end{array}$} \\
\hline Yes & 495 (48.9) & $297(57.0)$ & $90(32.8)$ & $56(48.3)$ & $32(54.0)$ & $18(46.2)$ \\
\hline No & $229(22.6)$ & $89(17.0)$ & $81(29.6)$ & $29(24.6)$ & $20(33.3)$ & $10(25.6)$ \\
\hline Uncertain & $289(28.5)$ & $136(26.0)$ & $103(37.6)$ & $32(27.1)$ & $8(12.7)$ & $11(28.2)$ \\
\hline
\end{tabular}

TABLE 3: HBV knowledge of survey respondents.

\begin{tabular}{ll}
\hline Hepatitis B knowledge & $N(\%)$ \\
\hline Knowledge level & $778(76.8)$ \\
Reasonable knowledge ( $\geq 7$ correct answers) & $235(23.2)$ \\
Not reasonable knowledge ( $\leq 6$ correct answers) & $130(12.8)$ \\
Low knowledge ( $\leq 4$ correct answers) & \\
Knowledge question [correct response] & $621(61.3)$ \\
In most cases, hepatitis B is only a temporary infection (like the flu) [false] & $625(61.7)$ \\
Hepatitis B is a cause of cirrhosis (severe scarring of liver) [true] & $631(62.3)$ \\
Hepatitis B is a cause of liver cancer [true] & $689(68.0)$ \\
Hepatitis B can be transmitted through an infected mother to her child [true] & $379(37.4)$ \\
Hepatitis B is a sexually transmitted disease [true] & $267(26.4)$ \\
Hepatitis B can be transmitted by sharing food or utensils of an infected person [false] & $854(84.3)$ \\
Hepatitis B can be diagnosed by blood tests [true] & $720(71.1)$ \\
A vaccine that can prevent hepatitis B exists [true] & $538(53.1)$ \\
There is effective treatment for hepatitis B [true] & $619(61.1)$ \\
Hepatitis B is more common in China and Asia versus North America [true] & $760(75.0)$ \\
Little children can have hepatitis B [true] & $669(66.0)$ \\
Hepatitis B affects adults [true] & $800(79.0)$ \\
Hepatitis B is preventable [true]
\end{tabular}

has been well documented in the literature $[7,12,17-21,27$, 33-39]. In addition, both higher education [7, 14, 40, 41] and higher HBV knowledge [7-16] have been associated with increased rates of HBV screening and vaccination. On the other hand, greater levels of HBV stigma have been associated with a decreased likelihood of HBV screening [8]. These findings provide support for the notion that knowledge dictates behavior in the setting of HBV.

Respondents in our study expressed high levels of concern (49\%) and desire (55\%) for further HBV education in the community. Moreover, many respondents felt that, compared to other major chronic diseases, $\mathrm{HBV}$ is receiving the least funding support from the $\mathrm{BC}$ government for preventive health education. The most common source of health information reported by our respondents was doctor's office which has been shown to be effective in increasing HBV knowledge and screening. Indeed, student-run clinics at the University of
California San Francisco providing community health education were shown to significantly improve the HBV knowledge of patients [42]. In addition, physician recommendation was identified as a positive predictor of $\mathrm{HBV}$ testing in Vietnamese Americans [15]. Finally, $80 \%$ of our respondents indicated a preference for $\mathrm{HBV}$ education in their native languages, even though $88 \%$ were bilingual. Indeed, language difficulty was identified as a significant barrier to health care in HBV among Chinese immigrants in Toronto [5]. On the other hand, English as a second language (ESL) educational curriculum was found to be effective in increasing $\mathrm{HBV}$ knowledge among Chinese immigrants in Vancouver [43]. These findings highlight the importance of providing community health education in a culturally sensitive manner.

There were several limitations in our study. First, households with unlisted telephone numbers were not included in our sample. Second, respondents to the survey may have 
TABLE 4: Predictors of HBV knowledge from multivariate analysis.

\begin{tabular}{|c|c|c|}
\hline Characteristics & Odds ratio $(95 \% \mathrm{CI})$ & $p$ value \\
\hline \multicolumn{3}{|l|}{ Age } \\
\hline $19-24$ & $1.8(0.9-3.5)$ & 0.084 \\
\hline $25-39$ & $1.7(1.1-2.7)$ & $0.022^{*}$ \\
\hline $40-54$ & $2.0(1.3-3.0)$ & $0.001^{*}$ \\
\hline \multirow[t]{2}{*}{$\geq 55$} & 1.0 & - \\
\hline & & $p($ trend $)=0.014^{*}$ \\
\hline \multicolumn{3}{|l|}{ Education } \\
\hline Primary/elementary & $0.3(0.1-0.5)$ & $<0.0001^{*}$ \\
\hline Secondary & $0.5(0.3-0.7)$ & $0.001^{*}$ \\
\hline Postsecondary & $0.7(0.4-1.1)$ & 0.116 \\
\hline \multirow[t]{2}{*}{ University or above } & 1.0 & - \\
\hline & & $p($ trend $)<0.0001^{*}$ \\
\hline \multicolumn{3}{|l|}{ Ethnicity } \\
\hline Chinese (Cantonese and Mandarin) & 1.0 & - \\
\hline South Asian & $0.3(0.2-0.4)$ & $<0.0001^{*}$ \\
\hline Filipino & $0.3(0.2-0.6)$ & $<0.0001^{*}$ \\
\hline Korean & $0.3(0.1-0.5)$ & $<0.0001^{*}$ \\
\hline Southeast Asian & $0.3(0.1-0.6)$ & $0.001^{*}$ \\
\hline \multicolumn{3}{|l|}{ Media for health information } \\
\hline No & $0.6(0.4-0.8)$ & $0.001^{*}$ \\
\hline Yes & 1.0 & - \\
\hline \multicolumn{3}{|l|}{ Internet for health information } \\
\hline No & $0.6(0.4-0.9)$ & $0.024^{*}$ \\
\hline Yes & 1.0 & - \\
\hline
\end{tabular}

TABLE 5: Predictors of knowledge that HBV may cause cirrhosis from multivariate analysis.

\begin{tabular}{|c|c|c|}
\hline Characteristics & Odds ratio $(95 \% \mathrm{CI})$ & $p$ value \\
\hline \multicolumn{3}{|l|}{ Education } \\
\hline Primary/elementary & $0.3(0.2-0.5)$ & $<0.0001^{*}$ \\
\hline Secondary & $0.7(0.5-1.0)$ & 0.073 \\
\hline Postsecondary & $0.7(0.5-1.0)$ & $0.039^{*}$ \\
\hline \multirow[t]{2}{*}{ University or above } & 1.0 & - \\
\hline & & $p($ trend $)<0.0001^{*}$ \\
\hline \multicolumn{3}{|l|}{ Ethnicity } \\
\hline Chinese (Cantonese and Mandarin) & 1.0 & - \\
\hline South Asian & $0.2(0.2-0.3)$ & $<0.0001^{*}$ \\
\hline Filipino & $0.3(0.2-0.5)$ & $<0.0001^{*}$ \\
\hline Korean & $0.4(0.2-0.8)$ & $<0.0001^{*}$ \\
\hline Southeast Asian & $0.1(0.1-0.3)$ & 0.001 \\
\hline \multicolumn{3}{|l|}{ Media for health information } \\
\hline No & $0.7(0.5-0.9)$ & $0.009^{*}$ \\
\hline Yes & 1.0 & - \\
\hline \multicolumn{3}{|l|}{ Doctor's office for health information } \\
\hline No & $1.6(1.2-2.2)$ & $0.001^{*}$ \\
\hline Yes & 1.0 & - \\
\hline
\end{tabular}


TABLE 6: Opinions on HBV education by survey respondents.

\begin{tabular}{|c|c|c|c|c|c|c|}
\hline HBV education & $\begin{array}{c}\text { Total } \\
(N=1013)\end{array}$ & $\begin{array}{l}\text { Chinese } \\
(N=522)\end{array}$ & $\begin{array}{l}\text { South Asian } \\
(N=274)\end{array}$ & $\begin{array}{l}\text { Filipino } \\
(N=117)\end{array}$ & $\begin{array}{l}\text { Korean } \\
(N=60)\end{array}$ & $\begin{array}{l}\text { Southeast } \\
\text { Asian } \\
(N=39)\end{array}$ \\
\hline \multicolumn{7}{|c|}{$\begin{array}{l}\text { Is hepatitis B education adequate in the } \\
\text { community? }\end{array}$} \\
\hline Yes & $208(20.5)$ & $66(12.7)$ & $62(22.3)$ & $42(35.6)$ & $30(49.2)$ & $8(20.5)$ \\
\hline No & $555(54.8)$ & $322(61.7)$ & $153(55.8)$ & $40(33.9)$ & $20(33.3)$ & $21(53.8)$ \\
\hline Uncertain & $250(24.7)$ & $134(25.6)$ & $60(21.9)$ & $35(30.5)$ & $10(17.5)$ & $10(25.6)$ \\
\hline \multicolumn{7}{|c|}{$\begin{array}{l}\text { Which language is more effective for } \\
\text { hepatitis education in the Asian } \\
\text { community? }\end{array}$} \\
\hline Native language & $811(80.1)$ & $446(85.5)$ & $244(89.1)$ & $48(40.7)$ & $47(76.2)$ & $27(69.2)$ \\
\hline English & $51(5.1)$ & $15(2.9)$ & $11(4.0)$ & $15(12.7)$ & $6(9.5)$ & $5(12.8)$ \\
\hline No difference & $152(14.8)$ & $61(11.6)$ & $19(6.9)$ & $54(46.6)$ & $8(14.3)$ & $7(17.9)$ \\
\hline \multicolumn{7}{|c|}{$\begin{array}{l}\text { What is your main source of health } \\
\text { information? }\end{array}$} \\
\hline Doctor's office & $588(58.1)$ & $228(43.7)$ & $202(73.7)$ & $88(75.4)$ & $40(65.1)$ & $30(76.9)$ \\
\hline Pharmacist & $182(17.9)$ & $73(13.9)$ & $24(8.8)$ & $37(31.4)$ & $32(52.4)$ & $15(38.5)$ \\
\hline Family and friends & $274(27.5)$ & $124(23.7)$ & $47(17.2)$ & $55(46.6)$ & $33(54.0)$ & $20(51.3)$ \\
\hline Internet & $436(40.9)$ & $249(47.6)$ & $61(22.3)$ & $71(61.0)$ & $16(25.4)$ & $18(46.2)$ \\
\hline Media & $395(40.4)$ & $243(46.6)$ & $75(27.4)$ & $58(49.2)$ & $14(22.2)$ & $20(51.3)$ \\
\hline School & $132(13.4)$ & 79 (15.2) & $5(1.8)$ & $34(28.8)$ & $10(15.9)$ & $8(20.5)$ \\
\hline Other & $61(6.0)$ & $30(5.8)$ & $17(6.2)$ & $12(10.2)$ & $1(1.6)$ & $1(2.6)$ \\
\hline Uncertain & $20(1.7)$ & $11(2.1)$ & $5(1.8)$ & 0 & 0 & $1(2.6)$ \\
\hline \multicolumn{7}{|c|}{$\begin{array}{l}\text { Is hepatitis B education receiving } \\
\text { sufficient governmental funding? }\end{array}$} \\
\hline Sufficient & $190(19.0)$ & 78 (14.9) & $51(18.8)$ & $34(31.2)$ & $16(26.7)$ & $11(29.7)$ \\
\hline Insufficient & $290(29.0)$ & $209(40.0)$ & $43(15.9)$ & $17(15.6)$ & $12(20.0)$ & $9(24.3)$ \\
\hline Neither & $90(9.0)$ & 37 (7.1) & $5(1.8)$ & $26(23.9)$ & $13(21.7)$ & $7(18.9)$ \\
\hline Uncertain & $430(43.0)$ & $199(38.0)$ & $171(63.1)$ & $33(30.3)$ & $19(31.7)$ & $10(27.0)$ \\
\hline
\end{tabular}

had higher levels of knowledge and increased rates of testing compared to those who refused to participate. Third, selfreported rates of $\mathrm{HBV}$ screening are subject to recall bias and may be inaccurate. Finally, our study did not collect data on rates of $\mathrm{HBV}$ vaccination.

In summary, there is an urgent need to raise public awareness and knowledge of $\mathrm{HBV}$ in order to avert its perpetuation in the community. HBV education should discuss (1) screening of high-risk individuals from highly endemic areas; (2) routes of transmission and precautions to avoid infecting others; (3) vaccination of family members and sexual contacts; (4) monitoring of ALT and HBV DNA and surveillance for HCC with abdominal ultrasound; and (5) potential benefit of highly efficacious and well tolerated antiviral therapy in chronic carriers.

\section{Conclusion}

Compared to the Chinese population, other Asian ethnic groups appear to have less awareness and knowledge of HBV. There are both a concern and a desire for further HBV education among Asian immigrant populations in BC. Public education should target older and less educated and South Asian, Filipino, Korean, and Southeast Asian populations in their native languages via media and Internet.

\section{Competing Interests}

Dr. Eric Yoshida is an investigator of clinical trials sponsored by Gilead Sciences, AbbVie, Janssen, Merck, and Boehringer Ingelheim. He has received honoraria for CME lectures sponsored by Gilead Sciences Canada and Merck Canada. He has provided Ad Board lectures for AbbVie Canada, Boehringer Ingelheim, and Celgene Canada. He has been a member of a compassionate release advisory committee sponsored by Gilead Sciences.

\section{References}

[1] N. Previsani and D. Lavanchy, Hepatitis B, CSR (Document WHO/CDS/CSR/LYO/2002.2:Hepatitis B), WHO Department of Communicable Disease Surveillance and Response, Geneva, Switzerland, 2002, http://www.who.int/csr/disease/hepatitis/ whocdscsrlyo20022/en. 
[2] Public Health Agency of Canada, "Hepatitis B-Get the Facts," June 2015, http://www.phac-aspc.gc.ca/hcai-iamss/bbp-pts/ hepatitis/hep_b-eng.php.

[3] Statistics Canada, "2006 Census of Population," June 2015, http://www.statcan.gc.ca/tables-tableaux/sum-som/101/cst01/ demo26k-eng.htm.

[4] T. G. Hislop, C. Teh, A. Low et al., "Hepatitis B knowledge, testing and vaccination levels in Chinese immigrants to British Columbia, Canada," Canadian Journal of Public Health, vol. 98, no. 2, pp. 125-129, 2007.

[5] H. Wu, C. Yim, A. Chan, M. Ho, and J. Heathcote, "Sociocultural factors that potentially affect the institution of prevention and treatment strategies for hepatitis B in Chinese Canadians," Canadian Journal of Gastroenterology, vol. 23, no. 1, pp. 31-36, 2009.

[6] World Health Organization, Hepatitis B (Fact Sheet no. 204), World Health Organization, Geneva, Switzerland, 2008.

[7] M. J. Thompson, V. M. Taylor, Y. Yasui et al., "Hepatitis B knowledge and practices among Chinese Canadian Women in Vancouver, British Columbia," Canadian Journal of Public Health, vol. 94, no. 4, pp. 281-286, 2003.

[8] D. Li, T. Tang, M. Patterson, M. Ho, J. Heathcote, and H. Shah, "The impact of hepatitis B knowledge and stigma on screening in Canadian Chinese persons," Canadian Journal of Gastroenterology, vol. 26, no. 9, pp. 597-602, 2012.

[9] M. Gürakar, M. Malik, O. Keskin, and R. Idilman, "Public awareness of hepatitis B infection in Turkey as a model of universal effectiveness in health care policy," Turkish Journal of Gastroenterology, vol. 25, no. 3, pp. 304-308, 2014.

[10] M. Xiong, R. H. N. Nguyen, L. Strayer, S. Chanthanouvong, and J.-M. Yuan, "Knowledge and behaviors toward hepatitis B and the hepatitis B vaccine in the Laotian community in Minnesota," Journal of Immigrant and Minority Health, vol. 15, no. 4, pp. 771778, 2013.

[11] Y. J. J. van der Veen, H. A. C. M. Voeten, O. de Zwart, and J. H. Richardus, "Awareness, knowledge and self-reported test rates regarding Hepatitis B in Turkish-Dutch: a survey," BMC Public Health, vol. 10, article 512, 2010.

[12] A. S. Khan, M. Al-Sweilem, and Z. Akturk, "Knowledge of hepatitis B and vaccination status of some expatriate ethnic groups of blue collar workers in northern Saudi Arabia," Journal of Family and Community Medicine, vol. 15, no. 2, pp. 77-83, 2008.

[13] J. P. Hwang, C.-H. Huang, and J. K. Yi, "Knowledge about hepatitis B and predictors of hepatitis $\mathrm{B}$ vaccination among Vietnamese American college students," Journal of American College Health, vol. 56, no. 4, pp. 377-382, 2008.

[14] C. A. Wu, S. Y. Lin, S. K. So, and E. T. Chang, "Hepatitis b and liver cancer knowledge and preventive practices among Asian Americans in the San Francisco Bay Area, California," Asian Pacific Journal of Cancer Prevention, vol. 8, no. 1, pp. 127-134, 2007.

[15] V. M. Taylor, Y. Yasui, N. Burke, J. H. Choe, E. Acorda, and J. C. Jackson, "Hepatitis B knowledge and testing among Vietnamese-American women," Ethnicity and Disease, vol. 15, no. 4, pp. 761-767, 2005.

[16] N. P. Fong, H. Basir, and A. Seow, "Awareness and acceptance of hepatitis B vaccination in Clementi, Singapore," Annals of the Academy of Medicine Singapore, vol. 19, no. 6, pp. 788-792, 1990.

[17] J. Cheung, T. K. Lee, C.-Z. Teh, C. Y. M. Wang, W. C. P. Kwan, and E. M. Yoshida, "Cross-sectional study of hepatitis
B awareness among Chinese and Southeast Asian Canadians in the Vancouver-Richmond community," Canadian Journal of Gastroenterology, vol. 19, no. 4, pp. 245-249, 2005.

[18] H.-O. Lee, O.-J. Lee, S. Kim, I. Hontz, and A. Warner, "Differences in knowledge of hepatitis B among Korean immigrants in two cities in the Rocky Mountain Region," Asian Nursing Research, vol. 1, no. 3, pp. 165-175, 2007.

[19] C. Chrusch and G. Y. Minuk, "Public knowledge about hepatitis B-related issues in Korea," Canadian Journal of Infectious Diseases, vol. 7, no. 1, pp. 53-55, 1996.

[20] N. Noreen, R. Kumar, and B. T. Shaikh, "Knowledge about hepatitis $\mathrm{B}$ vaccination among women of childbearing age: a cross-sectional study from a rural district of Punjab, Pakistan," Eastern Mediterranean Health Journal, vol. 21, no. 2, pp. 129-133, 2015.

[21] N. Ul Haq, M. A. Hassali, A. A. Shafie et al., "A crosssectional assessment of knowledge, attitude and practice among Hepatitis-B patients in Quetta, Pakistan," BMC Public Health, vol. 13, article 448, 2013.

[22] A. M. Thaver and A. Kamal, "Impact of information sources on the knowledge of adolescents about hepatitis B," Journal of the Pakistan Medical Association, vol. 60, no. 12, pp. 1072-1075, 2010.

[23] G. Haider and A. Haider, "Awareness of women regarding hepatitis B," Journal of Ayub Medical College Abbottabad, vol. 20, no. 4, pp. 141-144, 2008.

[24] A. K. Khuwaja, R. Qureshi, and Z. Fatmi, "Knowledge about hepatitis $\mathrm{B}$ and $\mathrm{C}$ among patients attending family medicine clinics in Karachi," Eastern Mediterranean Health Journal, vol. 8, no. 6, pp. 787-793, 2002.

[25] J. Kue and S. Thorburn, "Hepatitis B knowledge, screening, and vaccination among Hmong Americans," Journal of Health Care for the Poor and Underserved, vol. 24, no. 2, pp. 566-578, 2013.

[26] N. B. Ha, H. N. Trinh, T. T. Nguyen et al., "Prevalence, risk factors, and disease knowledge of chronic hepatitis B infection in Vietnamese Americans in California," Journal of Cancer Education, vol. 28, no. 2, pp. 319-324, 2013.

[27] R. Mohamed, C. J. Ng, W. T. Tong, S. Z. Abidin, L. P. Wong, and W. Y. Low, "Knowledge, attitudes and practices among people with chronic hepatitis B attending a hepatology clinic in Malaysia: a cross sectional study," BMC Public Health, vol. 12, article 601, 2012.

[28] L. H. Vu, Z. Gu, J. Walton et al., "Hepatitis B knowledge, testing, and vaccination among Chinese and Vietnamese adults in Australia," Asia-Pacific Journal of Public Health, vol. 24, no. 2, pp. 374-384, 2012.

[29] G. X. Ma, S. E. Shive, C. Y. Fang et al., "Knowledge, attitudes, and behaviors of hepatitis B screening and vaccination and liver cancer risks among Vietnamese Americans," Journal of Health Care for the Poor and Underserved, vol. 18, no. 1, pp. 62-73, 2007.

[30] L. M. Butler, P. K. Mills, R. C. Yang, and M. S. Chen, "Hepatitis B knowledge and vaccination levels in California Hmong youth: implications for liver cancer prevention strategies," Asian Pacific Journal of Cancer Prevention, vol. 6, no. 3, pp. 401-403, 2005.

[31] J. M. Wiecha, "Differences in knowledge of hepatitis b among vietnamese, African-American, hispanic, and white adolescents in Worcester, Massachusetts," Pediatrics, vol. 104, no. 5, pp. 12121216, 1999.

[32] Y.-W. Huang and C.-H. Hung, "The effect of health education through the internet on university female students' hepatitis B knowledge and cognition," Journal of Clinical Nursing, vol. 18, no. 23, pp. 3342-3348, 2009. 
[33] B. Hajarizadeh, J. Wallace, J. Richmond, N. Ngo, and C. Enright, "Hepatitis B knowledge and associated factors among people with chronic hepatitis B," Australian and New Zealand Journal of Public Health, vol. 39, no. 6, pp. 563-568, 2015.

[34] N. Roushan, M. Nasiri Toosi, A. Meysamie, A.-R. Esteghamati, and H. Hajrassuliha, "Hepatitis B knowledge among Iranian adolescents: a national survey," Iranian Red Crescent Medical Journal, vol. 15, no. 12, Article ID el1558, 2013.

[35] A. B. Adeyemi, O. O. Enabor, I. A. Ugwu, F. A. Bello, and O. O. Olayemi, "Knowledge of hepatitis B virus infection, access to screening and vaccination among pregnant women in Ibadan, Nigeria," Journal of Obstetrics and Gynaecology, vol. 33, no. 2, pp. 155-159, 2013.

[36] V. M. Taylor, J. C. Jackson, N. Chan, A. Kuniyuki, and Y. Yasui, "Hepatitis B knowledge and practices among Cambodian American women in Seattle, Washington," Journal of Community Health, vol. 27, no. 3, pp. 151-163, 2002.

[37] V. M. Taylor, J. C. Jackson, M. Pineda, P. Pham, M. Fischer, and Y. Yasui, "Hepatitis B knowledge among Vietnamese immigrants: implications for prevention of hepatocellular carcinoma," Journal of Cancer Education, vol. 15, no. 1, pp. 51-55, 2000.

[38] H. Li, C. J. Liu, and F. Q. Li, “The analysis on the hepatitis B awareness and factors influencing of reproductive women in poverty rural areas of Gansu province," Zhongguo Yi Miao He Mian Yi, vol. 15, no. 3, pp. 263-266, 2009.

[39] N. Y. Ashri, "Hepatitis B and C knowledge among Saudi dental patients," Saudi Medical Journal, vol. 29, no. 12, pp. 1785-1790, 2008.

[40] C. M. Leung, W. H. Wong, K. H. Chan et al., "Public awareness of hepatitis B infection: a population-based telephone survey in Hong Kong," Hong Kong Medical Journal, vol. 16, no. 6, pp. 463469, 2010.

[41] G. X. Ma, S. E. Shive, J. I. Toubbeh, Y. Tan, and D. Wu, "Knowledge, attitudes, and behaviors of Chinese hepatitis B screening and vaccination," American Journal of Health Behavior, vol. 32, no. 2, pp. 178-187, 2008.

[42] D. Ouyang, N. Yuan, L. Sheu, G. Lau, C. Chen, and C. J. Lai, "Community health education at student-run clinics leads to sustained improvement in patients' hepatitis B knowledge," Journal of Community Health, vol. 38, no. 3, pp. 471-479, 2013.

[43] V. M. Taylor, C. The, W. Lam et al., "Evaluation of a hepatitis B educational ESL curriculum for Chinese immigrants," Canadian Journal of Public Health, vol. 100, no. 6, pp. 463-466, 2009. 


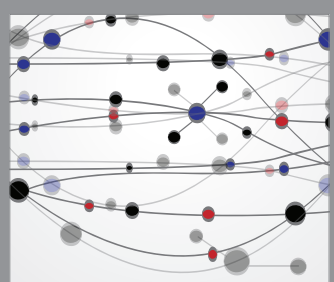

The Scientific World Journal
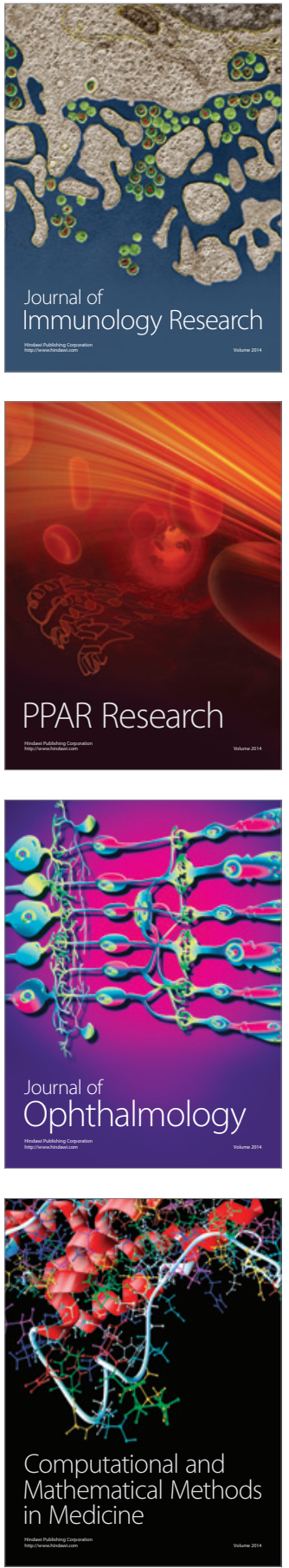

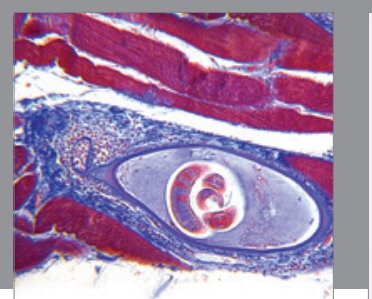

Gastroenterology Research and Practice

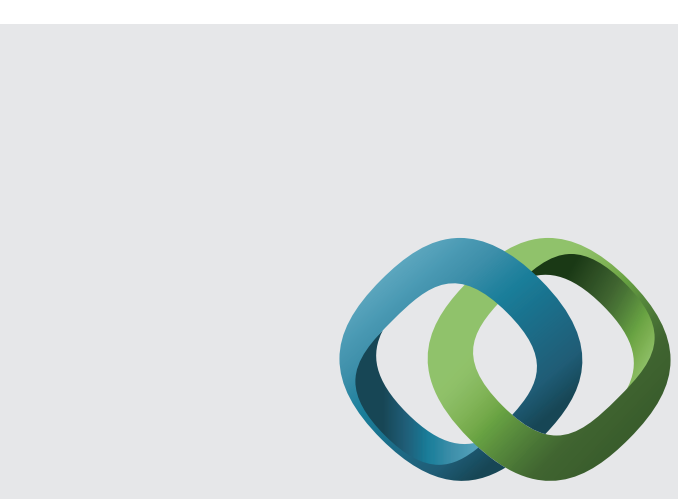

\section{Hindawi}

Submit your manuscripts at

http://www.hindawi.com
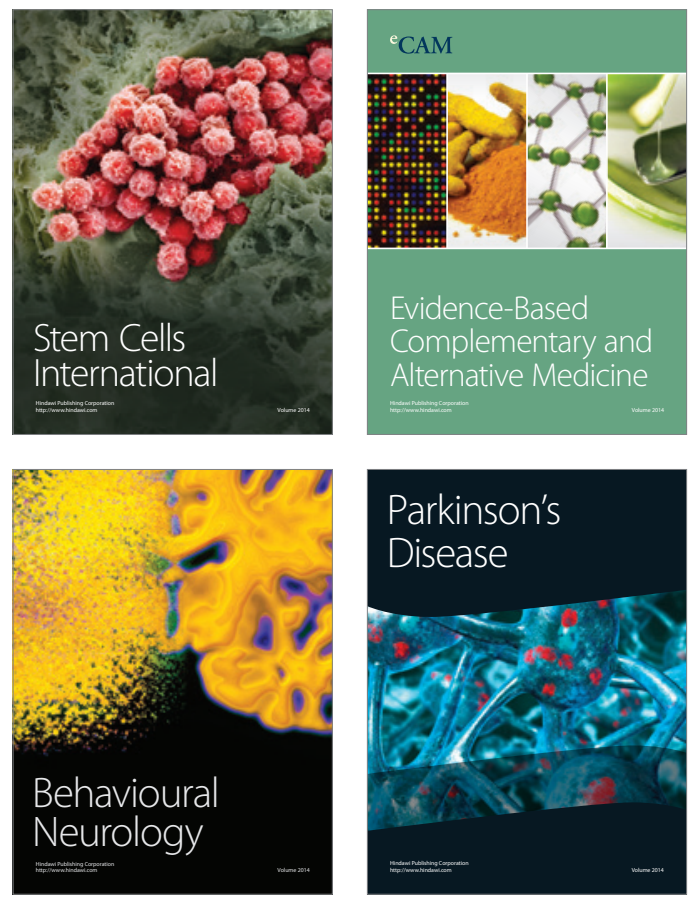
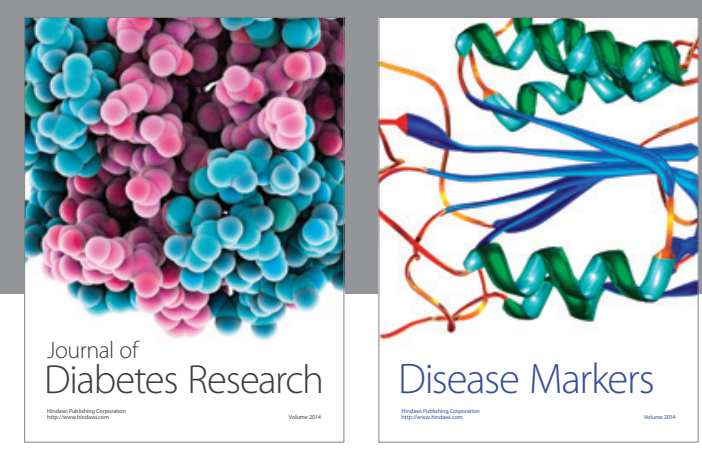

Disease Markers
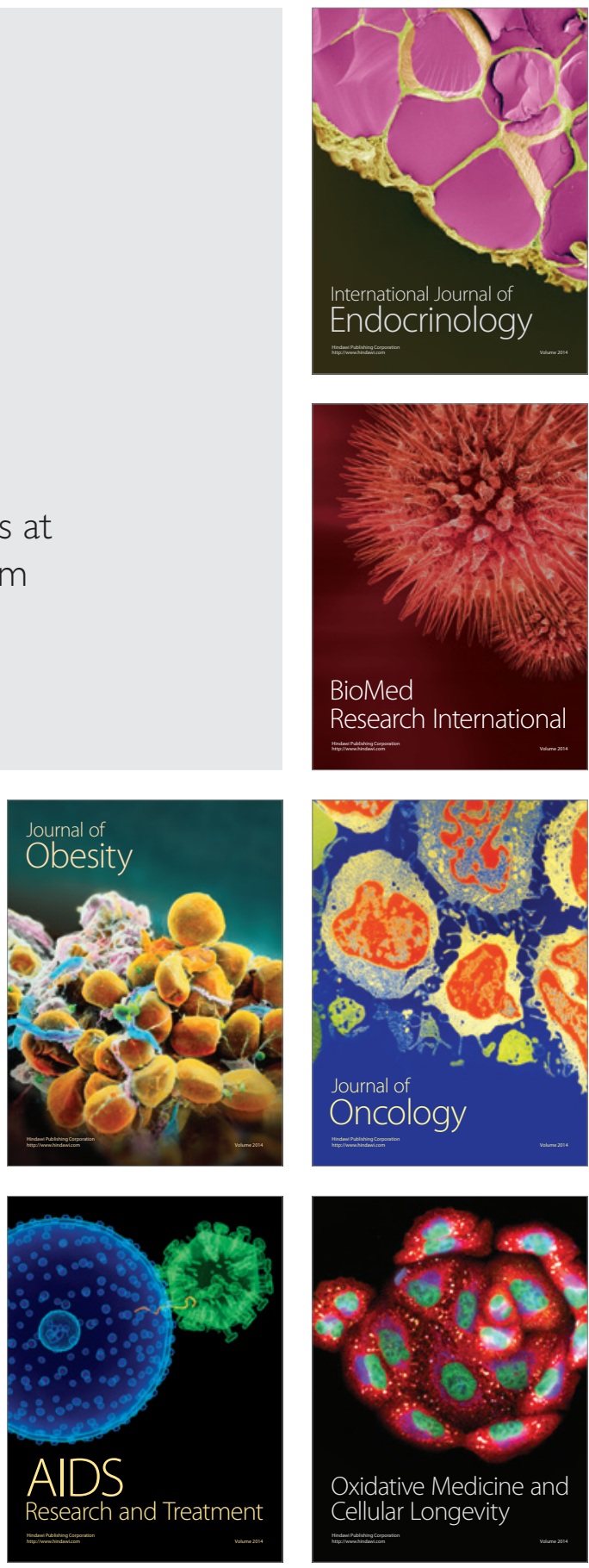